\title{
The Implementation of Edutainment Method in Preschool Learning
}

\author{
Neneng Tasuah \\ Early Childhood Teacher Education Departement, \\ Faculty of Science of Education \\ Seamarang State Universuty \\ nenengtasuah@gmail.com
}

\author{
Diana \\ Early Childhood Teacher Education Departement, \\ Faculty of Science of Education \\ Seamarang State Universuty \\ diana@mail.unnes.ac.id
}

\begin{abstract}
One method that can be used is the method of edutainment, which in this learning method is presented in the learning process of children is a learning process that is fun, comfortable and amazing, so the relationship between the teacher and the child can be established. Interactions between teachers and children will generate familiarity, and friends because of the learning process is done through the game presented by media attractivea ctivities. The purpose of this study is to provide an over view of edutainment application of the method in the learning activities and identify factors supporting and application of methods of edutainment in learning activities in kindergarten Islam Nasima. This study used a qualitative method with a case study approach which focuses only on the implementation of learning TKI Nasima.
\end{abstract}

\section{Keywords--edutainment; method; kindergarten}

\section{INTRODUCTION}

Many factors that affect the learning process of learners both externally and internally are identified as follows. There are still teachers who are lack of material knowledge of the theme discussed in the classroom and expect children to give the exact same answers as they were told; in other words, children are not given the opportunity to think creatively. Such teachers consider learning only as the task of transferring knowledge to the learners, so that the most important consideration is to have a textbook for themto be called teachers. One method that can be used is edutainment method, where in this learning method the learning process presented to children is a fun, comfortable and such an amazing learning process. This way, the relationship between teachers and children can be intertwined.

Nasima Islamic Kindergarten is one of the early childhood institutions that has produced many outstanding teachers in terms of management of learning through edutainment methods. The success of teachers in kindergarten is not an easy target to achieve, various aspects that can affect a teacher's success in teaching in the classroom are influenced by the methods used in the classroom. This research titled "The Implementation of Education Method in Learning Activity in Kindergarten (Case Study in Nasima Islamic Kindergarten, Semarang)", which later this research will give an idea about the form of application of edutainment method in learning activities in kindergarten.

\section{Research Questions}

a. How is the implementation of edutainment method in learning activitiesin Nasima Islamic Kindergarten?

b. What are the supporting and inhibiting factors of edutainment method implementation in learning process in Nasima Islamic Kindergarten?

\section{LITERATURE REVIEW}

\section{A. The Nature of Learning}

According to Mulyasa [1], learning is essentially the process of interaction between learners with the environment, so that there is a change in behavior to a better direction. In learning, the main task of teachers is to condition the environment in order to support the change of behavior for learners. This is in line with Berliner and Gage who argued that :

"Teaching methods are recurrent instructional processes, applicable to various subject matters, and usable by more than one teacher. The recurrent in that the activities are repeated over intervals measured in minutes or weeks. They are instructional processes, such asa patterned teacher behavior (for example, lecturing, discussion, and recitation)".

So it can be concluded that learning is very systematic and deliberate effort by educators to create conditions for learners to do learning activities. In this activity there is an educational interaction between two parties, i.e. between learners (student, learners, trainees and so on) who conduct learning activities.

\section{B. Edutainment Method}

According Moeslihatoen [2] method is part of strategy activities. Methods are selected based on the chosen and defined strategy.

Edutainment comes from the word education and entertainment. Sutrisno explained that Edutainment comes from the word "Education and Entertainment". Edutainment in terms of language means education that is entertaining or fun, 
in terms of edutainment terminology is a learning process designed in such a way that the content of education and entertainment can be combined in harmony so that learning is more fun, enjoyable learning is usually done with humor or games, role play and demonstration.

Some principles are characteristic of edutainment methods:

1. The concept of edutainment is a set of approaches in learning to bridge the gap that separates the teaching process and the learning process. The edutainment concept is designed to make learning process holistic, such as knowledge of how the brain works as well as memory, motivation, self-concept, emotions, learning styles, and other learning techniques.

2. The basic concept of edutainment seeks to make learning happen in a conducive and fun atmosphere. There are three assumptions on which to base: a) feelings of joy, b) develop positive child emotions, and c) optimize the potential of children's reasoning accurately and able to make learning achievements doubled.

3. Students who are educated properly, motivated, and taught in the right way (a way that values the child's style and desire), then the child will be able to achieve optimal learning outcomes.

\section{RESEARCH METHODOLOGY}

\section{A. Research Base}

Bogdan and Taylor in Moeloeng [3] defines a qualitative method as a research procedure that produces descriptive data in the form of written or oral words of people and behavior that can be observed. The reason used is qualitative research that researchers can trace and understand in depth about the matter studied, that is about the application of edutainment method in learning activity in kindergarten (Case study in Nasima Islamic Kindergarten, Semarang)

\section{B. Research Subject and Location.}

This research was carried out Nasima Islamic Kindergarten which is located at South Puspanjolo Street No. 53 Semarang. The subjects of this study were principals, teachers, and students in Nasima Islamic Kindergarten.

\section{Research Data Sources}

The source of research data is the subject where data can be obtained Arikunto [4]. So the sources of this research data are as follows:

1. Primary data sources are data sources obtained directly from the information in the field through interviews and observation. In connection with this, interviews and observations were made to teachers in Nasima Islamic Kindergarten.

2. Secondary data sources are data sources obtained indirectly from field informants such as documents and so forth. Secondary data used by researchers were in the form of documents and archive associated with the application of edutainment methods in Nasima Islamic Kindergarten.
D. Data Collection technique
1. Observation
2. Interview
3. Documentation

\section{E. Data Analysis Technique}

Data analysis technique was used to answer the problem formulation. In this research, data analysis was done by researcher by using a model from Miles and Huberman, they are data reduction, data presentation, and last is drawing conclusion.

\section{RESULTS AND DISCUSSION}

The discussion of research results is based on data description obtained by interview, observation and documentation in Nasima Islamic Kindergarten. Nasima Islamic Kindergarten applied the centers approach. The provided centers are as follows: preparation center 123 and a b c, building blocks center, natural materials center, role play center, game center and Nasima center. In the learning procces that takes place in the classroom, the teacher has applied edutainment method that is by giving opportunity to children to play and use various kinds of equipment that can be manipulated by them.

In role play center, before the activity took place, the teacher gave an explanation of the activities to be performed. The teacher offers the role that will be played to the child. Teachers also provide information about what items will be used in the role play activities. Then the teacher gives the child the freedom to play their respective roles. The teacher records all of their behaviors. At the end of the activity, the teacher asked the children what role they play. Then the teacher can also explore the vocabulary that the children have mastered and the introduction of numbers. Teachers allow children to explore things and also freely interact with their friends.

In addtion to the role play center, in the building blocks center, teacher provided an explanation of the activities to be implementetd. The teacher explained the material that was delivered. Then ask the children to make the rules that every child should agree on. Then the teacher asked the children to make a building using the block that have been available in the room. The teacher can determine what building can be made, tailored to the theme or subject matter that has been disccused together with the child. The results of the childres's work are then documented by photographing each child. In addtion to photographing their work, the teacher also asked the children about the building they created by presenting the result of their work.

The art activities center is usually associated with children's work. Children are given the opportunity to explore various equipments provided by the teacher. In this activity, 
children are also given the freedom to creativity in accordence with the idea. While in Nasima center, the activities are usually done with respect to religion. Children are accustomed to perform activities of worship in accordance with the religion they embrance. Starting from the introduction of worship such as prayer and reciting the Holy Qur'an together.

The implementation of edutainment method that has been done in Nasima Islamic Kindergarten is good, because the core of the edutainment method has been implemented. Every learning activity contains elements of game, role play and demonstration. The patterns of interaction that occur between teachers and students look familiar. Teachers can position themselves as teachers and can also be friends with students. So the children are not afraid to express their wishes and ideas to the tacher. In classroom learning, teachers are able to encourage children to think critically and provide opportunities to solve problems in various ways.

However sometimes there are obstacles that can disrupt the learning process. These constraints can be handled well by teachers. For example, there are children who do not want to follow activities that have been prepared by teachers, the children are then motivated to follow the activities instead of being forced. In addition to that, sometimes the media can also be an obstacle in the learning process. For example the use of puzzle that is incomplete because one or more pieces were lost. This can be overcome by printing the lost pieces so children can still learn to put the puzzle together. Therefore, the learning proces in Nasima Islamic Kindergarten is good and it has applied edutainment method despite the obstacles. All teachers and principals work together well for learning to work well.

\section{CONCLUSION}

The implementation of edutainment method has been implemented in Nasima Islamic Kindergarten in every learning activity. This is evident considering the fact that the learning has already contained the elements of game, role play and demonstrations. The application of edutainment methods sometimes has constraints, but the constraints can be overcome well. This is due to the cooperation between teachers and principals. They work together to give the best for their students.

\section{References}

[1] Mulyasa. 2002. Kurikulum berbasis kompetensi: konsep, karakteristik, dan implementasi. Jakarta: PT Remaja Rosdakarya.

[2] Moeslihatoen. 2004. Metode Pengajaran Di Taman Kanak-Kanak. Jakarta:PT Asdi Mahasatya

[3 ] Moleong, L. J. (2005). Metode Penelitian Kualitatif. Bandung: PT Remaja Rosdakarya Offset.

[4] Arikunto, S. (2006). Prosedur Penelitian Suatu Pendekatan Praktik. Jakarta: PT RINEKA CIPTA. 